\title{
The Association Between Borna Disease Virus and Mood Disorders: A
} Systematic Review and Meta-Analysis

\author{
Milad Azami, ${ }^{1}$ Farid Azizi Jalilian, ${ }^{2}$ Mohammad Reza Adhami Mojarad, ${ }^{3}$ Younes Mohammadi, ${ }^{4}$ and \\ Zeinab Tardeh ${ }^{1, *}$ \\ ${ }^{1}$ Student Research Committee, Faculty of Medicine, Ilam University of Medical Sciences, Ilam, IR Iran \\ ${ }^{2}$ Department of Virology, School of Medicine, Hamadan University of Medical Sciences, Hamadan, IR Iran \\ ${ }^{3}$ Department of Infectious Diseases, Faculty of Medicine, Ilam University of Medical Sciences, Ilam, IR Iran \\ ${ }^{4}$ Department of Epidemiology, Modeling of Noncommunicable Disease Research Center, School of Public Health, Hamadan University of Medical Sciences, Hamadan, IR Iran \\ "Corresponding author: Zeinab Tardeh (MD), Student Research Committee, Faculty of Medicine, Ilam University of Medical Sciences, Ilam, IR Iran. Tel: +98-9337416255, E-mail: \\ z.tardeh@gmail.com
}

Received 2017 July 08; Revised 2018 January 04; Accepted 2018 February 28.

\begin{abstract}
Context: Recent studies on patients with psychiatric disorders suggest a possible association between borna disease virus (BDV) and mood disorders. However, a clear association remains controversial. The current systematic review and meta-analysis study aimed at investigating the association between BDV infection and mood disorders.

Methods: The current study was conducted based on preferred reporting items for systematic reviews and meta-analyses (PRISMA) guidelines. To obtain the evidence, several databases were searched including PubMed, Scopus, ScienceDirect, Web of Science, Embase, Cochrane Library, PsycINFO, and Google Scholar search engine without time limit until 2017. Heterogeneity of the studies was assessed using $\mathrm{Q}$ test and $\mathrm{I}^{2}$ index. A random effect model was used to estimate the odds ratio (OR) with $95 \%$ confidence interval (CI). Results: Meta-analysis of 23 studies comprising 3628 cases and 5,810 controls showed that BDV infection was associated with a significantly increased risk of mood disorders ( $\mathrm{OR}=1.61 ; 95 \% \mathrm{CI}: 1.21-2.15, \mathrm{P}=0.001, \mathrm{I}^{2}=44 \%$ ). Subgroup analysis was used according to diagnostic method indicating OR was 1.01 (95\%CI: 0.37 - 2.8) for immunofluorescence antibody (IFA), 1.26 (95\%CI: 0.5 - 3.18) for western blot (WB) assay, 1.58 (95\%CI: 1.06 - 2.38) for real-time polymerase chain reaction (RT-PCR), 1.16 (95\%CI: 0.24 - 5.70) for radioligand assay (RLA), 2.55 (95\%CI: 1.67 - 3.88) for enzyme immunoassay (EIA), 2.15 (95\%CI: 0.68-6.80) for enzyme-linked immunosorbent assay (ELISA), 3.29 (95\%CI: 1.35 - 7.98) for electrochemiluminescence immunoassay (ECLIA), 4.00 (95\%CI: 0.89 - 17.87) for peptide array, and 1.00 (95\%CI: 0.23 - 4.27) for proliferation assay method. In subgroup analysis of bipolar and unipolar disorder, OR was 1.99 (95\%CI: $1.29-3.08, \mathrm{P}=0.002$ ) and $1.16(95 \% \mathrm{CI}: 0.76-1.76, \mathrm{P}=0.481)$, respectively.

Conclusions: These results can confirm the significant role of BDV infection in mood disorders. Therefore, it might be necessary to consider BDV infection to manage psychiatric disorders.
\end{abstract}

Keywords: Borna Disease Virus, Mood Disorder, Meta-Analysis

\section{Context}

A significant proportion of global burden of disease is caused by mental, neurological, and substance use disorders (1). A study conducted in 2015 reported the worldwide prevalence of mental disorders as $13.4 \%$, which is high (2). In some studies, low prevalence of psychiatric disorders was reported in the elderly, high prevalence of mood and anxiety disorders was reported in females, and substance use and several personality disorders were reported in males $(3,4)$.

Studies showed that mental disorders are a risk factor for blood borne infections (5-7). Borna disease virus (BDV) is one of the infections considered by some studies as a risk factor that might play a role in the development of neurological and psychiatric disorders. However, there is no consensus on whether BDV can infect human and cause neuropsychiatric disorders (8). BDV is a negative strand and negative polarity, non-segmented RNA virus belonging to order Mononegavirales that replicates in the cell nucleus $(9,10)$. BDV mainly infects the cortex and hippocampus neurons of limbic system and thus, may affect cognition and behavior (11).

Bechterand et al., detected BDV immunoglobulin G (IgG) in cerebrospinal fluid (CSF) specimen of patients with mood disorder and confirmed the role of BDV infection in the etiology of psychiatric disorders (12). In a study using real-time reverse transcriptase polymerase chain re- 
action (RRT-PCR) to detect BDV p24RNA in patients with mood disorder, the association between BDV infection and mood and other psychiatric disorders was reported (13). In another study by Li et al., using western blot (WB) assay and RT-PCR, BDV was detected in 6 patients with encephalitis, but not in the ones with other neurological disorders (14). No association was observed between BDV infection and psychiatric disorders including depressive, bipolar, and schizophrenia in a study using RRT-PCR and indirect immunofluorescence antibody (IFA) methods (15). Tsuji et al. compared patients with psychiatric disorders with a control group using RT-PCR and WB assay, but did not confirm the association between BDV infection and mood and other psychiatric disorders (16). In another study conducted in Iran, high prevalence of subclinical BDV infections and the association between BDV infection and mood disorders such as bipolar and major depressive disorders (MDD) was approved (17). The study by Horing et al. rejected the role of BDV infection in pathogenesis of psychiatric disorders such as bipolar, major depressive, and schizophrenia (18).

Moreover, the evidence indicated a possible association between BDV infection and mood disorders, but the exact association was not clear and many questions about this association remained unanswered.

\section{Objectives}

Systematic reviews and meta-analyses were the investigation methods to combine results of different studies into a single conclusion (19-21) and the current study aimed at finding the association between mood disorders and BDV infection.

\section{Methods:}

\subsection{Study Protocol}

The current study was conducted using the preferred reporting items for systematic reviews and meta-analyses (PRISMA) guidelines (20). To avoid bias, all steps of the study were performed by 2 researchers independently. A third author reviewed any disagreement between the 2 researchers.

\subsection{Data Sources}

To obtain the corresponding evidence, the following databases were searched: PubMed, Scopus, ScienceDirect, Web of Science, Embase, Cochrane Library, PsycINFO, and Google Scholar search engine as well as the reference list of the articles without time limit until 15 January 2017. The search was developed using the following keywords: "Borna Disease Virus"[MeSH], "Mood Disorders"[MeSH], “Mood Disorders"[MeSH], "Depression”[MeSH], "Depressive Disorder"[MeSH], "Bipolar Disorder”[MeSH], "Depressive Disorder, Major"[MeSH], “Infection”[MeSH], and “Mental Disorders"[MeSH].

\subsection{Inclusion and Exclusion Criteria}

The inclusion criteria were observational epidemiological studies (i e, case-control, cohort, and cross sectional) in English on human populations. Studies with insufficient data, irrelevant to the topic, without the outcome of mood disorders based on exposure to BDV along with a control group of healthy people for comparison, letter to editors, presentations, review articles, and case reports were excluded.

\subsection{Study Selection and Quality Assessment}

The primary screening was conducted to select relevant articles by screening title and abstract of the articles, and then the full text of the remaining articles were reviewed for eligibility. Finally, articles were assessed using the modified Newcastle Ottawa Scale (NOS) for non randomized studies and articles that got a minimum score of 7 were selected (22).

\subsection{Data Extraction}

The data of the selected articles including the name of the first author, country, year and design of study, name of journal, characteristics of samples (e g, sample size, gender, and mean age), diagnostic method, diagnostic criteria, odds ratio (OR), 95\% confidence interval (CI), and number of BDV positive subjects in the case and control groups were extracted and recorded in an Excel file.

\subsection{Data Analysis}

The data were analyzed using the Comprehensive Meta-Analysis ver. 2 software. OR was used with 95\% CIs as a selective association index and forest plot was used to present combined result and individual studies separately. To assess the heterogeneity of the studies, Cochran's $Q$ test and I2 statistic were used ( $\mathrm{I}^{2}$ index lower than $25 \%, 25 \%$ - 75\%, and higher than $75 \%$ was considered as low, moderate, and high heterogeneity, respectively) (23). Due to the heterogeneity of the studies, the random effect model was used to combine the study data. Subgroup analysis was performed according to diagnostic method and bipolar and unipolar 
disorders. The sensitivity analysis was employed to investigate the stability and reliability of data by deleting every single study from meta-analysis. To assess publication bias, the Egger and Begg's tests were used. The significance level was considered $<0.05$.

\section{Results}

\subsection{Search Results}

In the initial systematic search, 460 publications were found; 210 duplicates were excluded. After screening titles and abstracts of the 250 retained studies, 200 irrelevant ones were excluded. Then, the full texts of the remaining articles were studied and 27 articles were excluded (Figure 1).

\subsection{Characteristics of the included studies}

Finally, 23 eligible studies consisting of 3628 cases and 5810 controls entered the final analysis (Tables 1 and 2).

\subsection{The Association Between BDV and Mood Disorders}

The heterogeneity rate in the current study was moderate $\left(\mathrm{I}^{2}=44.43 \%, \mathrm{P}=0.005\right)$. Meta-analysis of 23 studies showed that BDV infection was associated with a significantly increased risk of mood disorders $(\mathrm{OR}=1.615 ; 95 \% \mathrm{CI}$ : $1.215-2.15, \mathrm{P}=0.001$ ) (Figure 2).

\subsection{Subgroup Analysis Based on Diagnostic Methods}

Subgroup analysis used according to diagnostic method indicated that OR was 1.01 (95\% CI: 0.37 - 2.8) for IFA, 1.26 (95\%CI: 0.5 - 3.18) for WB, 1.58 (95\%CI: 1.06 - 2.38) for RT-PCR, 1.16 (95\%CI: 0.24 - 5.70) for radioligand assay (RLA), 2.55 (95\%CI: 1.67 - 3.88) for enzyme immunoassay (EIA), 2.15 (95\%CI: 0.68 - 6.80) for enzyme-linked immunosorbent assay (ELISA), 3.29 (95\%CI: 1.35 - 7.98) for electrochemiluminescence immunoassay (ECLIA), 4.00 (95\%CI: 0.89 - 17.87) for peptide array, and 1.00 (95\%CI: 0.23 - 4.27) for proliferation assay (Figure 3 ).

\subsection{Subgroup Analysis Based on Patients with Bipolar/Unipolar Depressive Disorder}

In subgroup analysis of patients with bipolar/ unipolar depressive disorder, OR was 1.99 (95\%CI: 1.29 - 3.08, P = 0.002 ) and 1.16 (95\%CI: $0.76-1.76, \mathrm{P}=0.481$ ), respectively (Table 2).

\subsection{Publication Bias and Sensitivity Analysis}

Pvalues estimated for the publication bias in the Egger and Begg tests were 0.31 and 0.96 respectively, and the difference between them was not significant (Figure 4). In the sensitivity analysis, the impact of each study on the combined OR was determined by repeating the meta-analysis after removing 1 study, and the relationship was significant (Figure 5).

\section{Discussion}

In the current study, a significant association was noted between BDV infection and mood disorders by combining the results of 23 studies. After performing heterogeneity testing, the rate of heterogeneity in the current study was $44.43 \%$, which tended to moderate heterogeneity. Therefore, the random effect model was used. Subgroup analysis based on diagnostic methods and bipolar and unipolar disorders was used to detect the source of heterogeneity. Another possible source of heterogeneity was sample size and different types of mood disorders, which was not assessed in the current study. Subgroup analysis was conducted in patients with bipolar or unipolar depressive disorders, which was not significant in unipolar disorders and was significant in bipolar disorders. However, this result may be affected by the limited number of studies and small sample size.

Studies showed that humans are exposed to BDV (24). Evidence of the association between BDV infection and psychiatric disorders was observed in the study by Azami et al. By analyzing 35 studies, significant association was confirmed between BDV infection and schizophrenia, and the estimated OR was 2.72 (95\%CI: 1.75 - 4.20) (25). In another meta-analysis conducted in 2017 on 9 studies, a significant association was observed between BDV infection and chronic fatigue syndrome, and the estimated OR was 10.41 (95\%CI: 4.24 -25.55, P $<0.0001$ )(26). In addition, significant association was noted between BDV infection and depression in a meta-analysis by Wang et al. (27). However, no evidence of BDV infection was observed in patients with mental illnesses in a meta-analysis by Durrwald, suggesting the possible role of sample contamination in the result of previous studies (28).

One of limitations of the current study was lack of access to full texts of several articles. In addition, studies included in the analysis did not use the same methods, samples, and diagnostic indices, which may affect the results. Moreover, studies conducted on this issue were restricted to specific geographical regions. However, it was tried to use all studies conducted on the association between BDV 


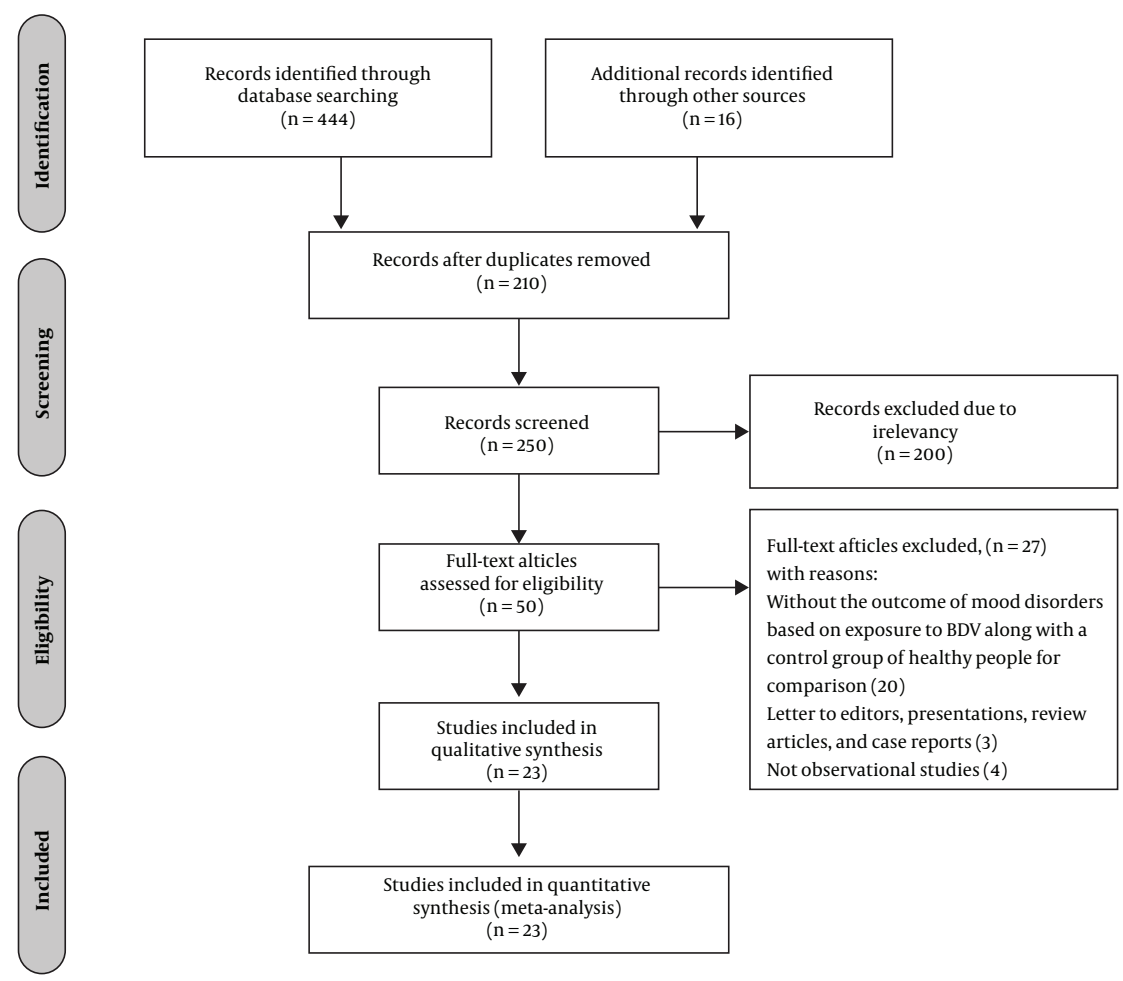

Figure 1. PRISMA Flowchart

Table 2. Data Obtained From Studies on the Association Between BDV Infection and Unipolar and Bipolar Disorders

\begin{tabular}{|c|c|c|c|c|c|}
\hline \multirow[t]{2}{*}{ Subtype } & \multirow[t]{2}{*}{ Study (N) } & \multirow[t]{2}{*}{$\mathrm{OR}(95 \% \mathrm{CI})$} & \multirow[t]{2}{*}{ P Value } & \multicolumn{2}{|c|}{ Heterogeneity } \\
\hline & & & & $I^{2}$ & P Value \\
\hline Unipolar disorder & 10 & $1.162(0.765-1.765)$ & 0.481 & 36.2 & 0.119 \\
\hline Bipolar disorder & 7 & $1.996(1.293-3.080)$ & 0.002 & 0 & 0.856 \\
\hline
\end{tabular}

Abbreviations: confidence interval (CI); number (N); odds ratio (OR).

and mood disorders and also the role of different methods in the final results using subgroup analysis. These variables may influence the result of the current and other studies, and their sensitivity and specificity were not similar to those of the study by Billich. According to the findings of the current study, the results of IFA and peptide array were different, which indicated lower sensitivity, but higher specificity of peptide array (29). However, according to the study by Fukuda using different methods such as ECLIA, RT-PCR, and WB in different samples of plasma and PBMC (peripheral blood mononuclear cell), the differences were not statistically significant (30). According to the study by $\mathrm{Na}$, BDV was not detected in any of the subjects in the case or control groups using IFA and RT-PCR methods
(15).

\section{Conclusions}

The current study confirmed the association between BDV infection and mood disorders and suggested the role of viral infections in the etiology of neuropsychiatric disorders. However, more studies in different regions of the world should be conducted to find the exact association and other etiologic agents should be determined. However, reliable diagnostic methods should be introduced. Understanding the underlying factors may help in prevention, diagnosis, and management of patients with psychiatric disorders and may help to reduce the rate of such disorders and their socio-economical burdens. 


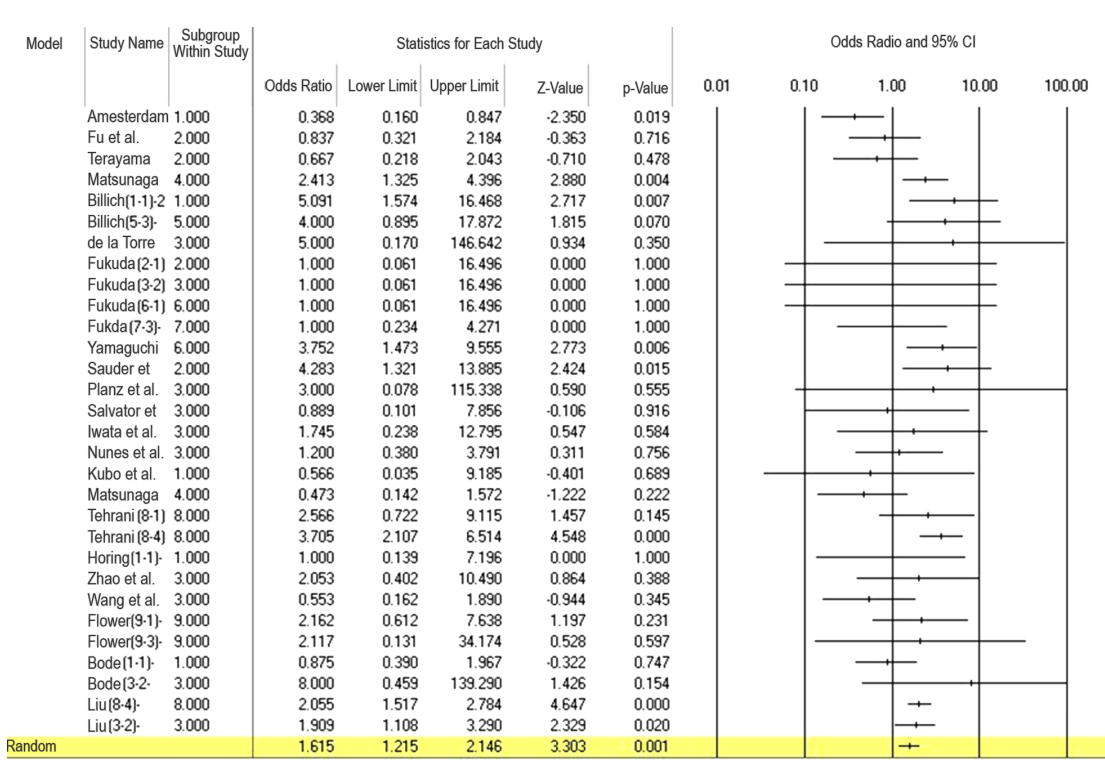

Figure 2. Meta-analysis of studies on association between BDV infection and mood disorders

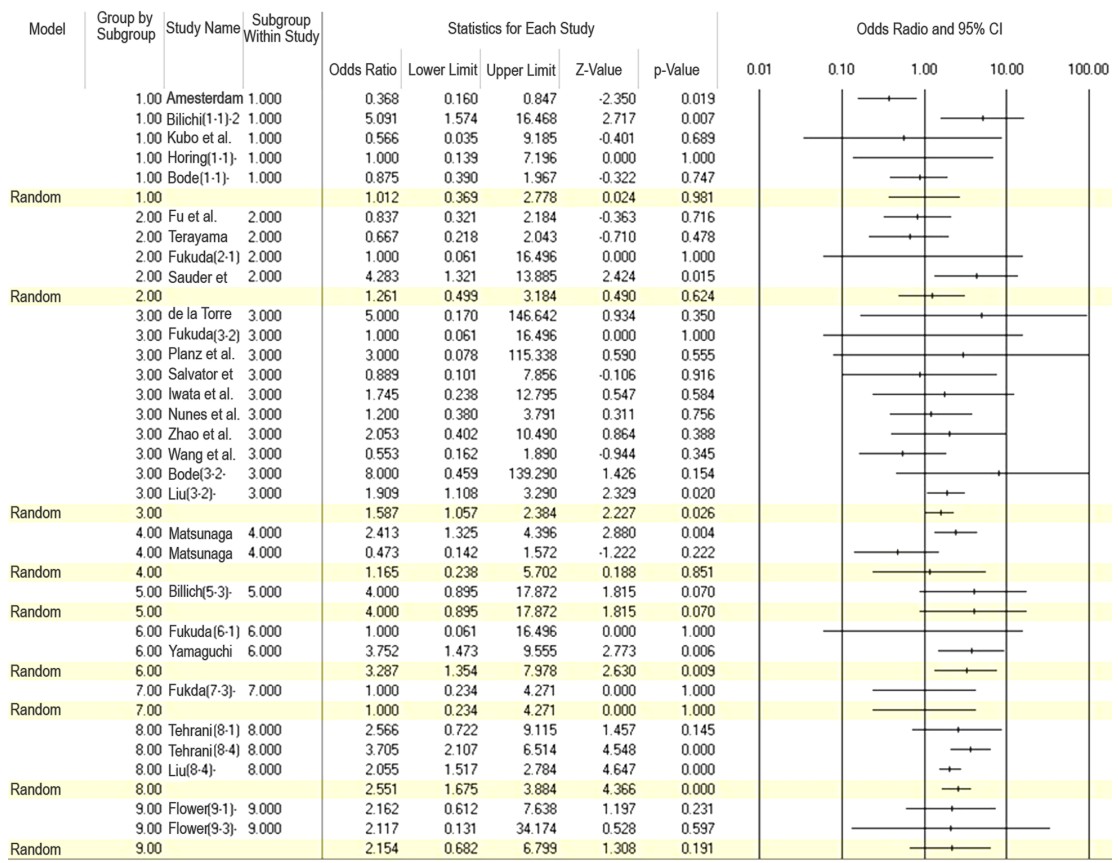

Figure 3. Meta-analysis of studies on the association between BDV infection and mood disorders according to diagnostic method; $(1=\mathrm{IFA}, 2=\mathrm{WB}, 3=\mathrm{RT}-\mathrm{PCR}, 4=\mathrm{RLA}, 5=$ peptide array, $6=$ ECLIA, $7=$ proliferation assay, $8=$ EIA, $9=$ ELISA). 


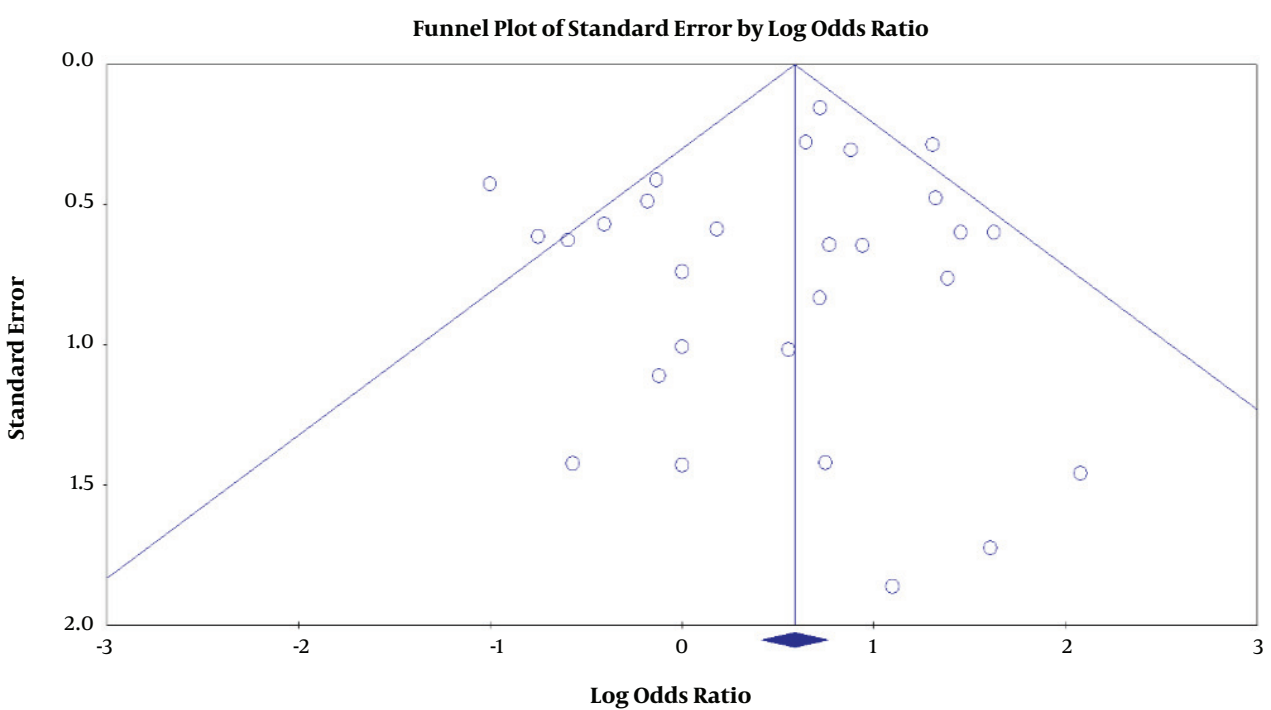

Figure 4. Publication bias in meta-analysis of studies on the association between BDV infection and mood disorders

\begin{tabular}{|c|c|c|c|c|c|c|c|c|c|}
\hline \multirow[t]{2}{*}{$\underline{\text { Study Name }}$} & \multicolumn{5}{|c|}{ Statistics With Study Removed } & & \multicolumn{2}{|c|}{ Odds Ratio $(95 \% \mathrm{Cl}$ ) With Study Removed } & \\
\hline & Point & $\begin{array}{c}\text { Lower } \\
\text { Limlit }\end{array}$ & $\begin{array}{l}\text { Upper } \\
\text { Limlit }\end{array}$ & Z-Value & p-Value & & & & \\
\hline Amesterdam et al- 1985 & 1.810 & 1.415 & 2.315 & 4.725 & 0.000 & & & I & \\
\hline Fu et al- 1993 & 1.670 & 1.250 & 2.230 & 3.470 & 0.001 & & & & \\
\hline Terayama et al- 2003 & 1.677 & 1.260 & 2.232 & 3.548 & 0.000 & & & & \\
\hline Matsunaga et al- 2008 & 1.563 & 1.155 & 2.115 & 2.895 & 0.004 & & & & \\
\hline Billich(1-1)-2002 & 1.548 & 1.164 & 2.059 & 3.002 & 0.003 & & & & \\
\hline Billich(5-3)- 2002 & 1.575 & 1.179 & 2.102 & 3.077 & 0.002 & & & & \\
\hline de la Torre et al- 1996 & 1.601 & 1.201 & 2.134 & 3.210 & 0.001 & & & & \\
\hline Fukuda(2-1) 2001 & 1.621 & 1.214 & 2.162 & 3.280 & 0.001 & & & & \\
\hline Fukuda(3-2)2001 & 1.621 & 1.214 & 2.162 & 3.280 & 0.001 & & & & \\
\hline Fukuda(6-1)- 2001 & 1.621 & 1.214 & 2.162 & 3.280 & 0.001 & & & & \\
\hline Fukda(7-3)- 2001 & 1.636 & 1.223 & 2.188 & 3.317 & 0.001 & & & & \\
\hline Yamaguchi et al -1999 & 1.548 & 1.158 & 2.069 & 2.951 & 0.003 & & & & \\
\hline Sauder et al- 1996 & 1.556 & 1.167 & 2.076 & 3.007 & 0.003 & & & & \\
\hline Planz et al- 1999 & 1.607 & 1.205 & 2.144 & 3.228 & 0.001 & & & & \\
\hline Salvator et al- 1997 & 1.628 & 1.220 & 2.173 & 3.307 & 0.001 & & & & \\
\hline Iwata et al- 1998 & 1.610 & 1.204 & 2.153 & 3.215 & 0.001 & & & & \\
\hline Nunes et al- 2008 & 1.632 & 1.217 & 2.189 & 3.269 & 0.001 & & & & \\
\hline Kubo et al- 1997 & 1.630 & 1.224 & 2.172 & 3.337 & 0.001 & & & & \\
\hline Matsunaga et al- 2005 & 1.697 & 1.284 & 2.244 & 3.713 & 0.000 & & & & \\
\hline Tehrani(8-1)- 2014 & 1.586 & 1.183 & 2.127 & 3.086 & 0.002 & & & & \\
\hline Tehrani(8-4)- 2014 & 1.517 & 1.142 & 2.015 & 2.875 & 0.004 & & & & \\
\hline Horing(1-1)- 2012 & 1.627 & 1.218 & 2.173 & 3.295 & 0.001 & & & & \\
\hline Zhao et al- 2007 & 1.603 & 1.197 & 2.146 & 3.171 & 0.002 & & & & \\
\hline Wang et al- 2006 & 1.683 & 1.268 & 2.233 & 3.603 & 0.000 & & & & \\
\hline Flower(9-1)- 2008 & 1.595 & 1.189 & 2.140 & 3.116 & 0.002 & & & & \\
\hline Flower(9-3)- 2008 & 1.609 & 1.205 & 2.148 & 3.224 & 0.001 & & & & \\
\hline Bode(1-1)- 1992 & 1.676 & 1.255 & 2.240 & 3.494 & 0.000 & & & & \\
\hline Bode(3-2- 1995 & 1.591 & 1.196 & 2.118 & 3.186 & 0.001 & & & & \\
\hline Liu(8-4)- 2015 & 1.568 & 1.138 & 2.161 & 2.748 & 0.006 & & & & \\
\hline \multirow[t]{4}{*}{ Liu(3-2)- 2015} & 1.587 & 1.167 & 2.158 & 2.943 & 0.003 & & & & \\
\hline & 1.615 & 1.215 & 2.146 & 3.303 & 0.001 & & & & \\
\hline & & & & & & 0.01 & 0.1 & 10 & 100 \\
\hline & & & & & & & Favours A & =avours B & \\
\hline
\end{tabular}

Meta Analysis

Figure 5. Sensitivity analysis in meta-analysis of studies on the association between BDV infection and mood disorders 
Table 1. Data Obtained From Studies on the Association Between BDV Infection and Mood Disorders

\begin{tabular}{|c|c|c|c|c|c|c|c|c|c|c|c|c|}
\hline \multirow[t]{2}{*}{ Authors Name } & \multirow[t]{2}{*}{ Year } & \multirow[t]{2}{*}{ Place } & \multicolumn{4}{|c|}{ Case } & \multicolumn{4}{|c|}{ Control } & \multirow[t]{2}{*}{ Assay } & \multirow[t]{2}{*}{ Technique/Sample } \\
\hline & & & $\begin{array}{c}\text { BDV } \\
\text { Positive }\end{array}$ & BDV Negative & Male/Female & $\begin{array}{l}\text { Mean Age } \\
\text { (SD) }\end{array}$ & $\begin{array}{c}\text { BDV } \\
\text { Positive }\end{array}$ & $\begin{array}{c}\text { BDV } \\
\text { Negative }\end{array}$ & Male/Female & $\begin{array}{l}\text { Mean Age } \\
\text { (SD) }\end{array}$ & & \\
\hline Yamaguchi et al. (31) & 1999 & Japan & 9 & 242 & $98 / 153$ & $55.6(14)$ & 10 & 907 & $632 / 285$ & $35.1(13.1)$ & $\begin{array}{l}\text { Anti p24 and } \\
\text { p40 Ab }\end{array}$ & ECLIA/Serum \\
\hline Amesterdam et al. (32) & 1985 & USA & 12 & 253 & & & 0 & 105 & & & Anti BDV Ab & IFA/Serum \\
\hline Fu et al. (33) & 1993 & USA & 9 & 129 & $41 / 97$ & $40(13)$ & 1 & 116 & $77 / 40$ & $34(10)$ & $\begin{array}{c}\text { Anti } 38 / 40 \text { and } \\
\text { 24kDa protein } \\
\mathrm{Ab}\end{array}$ & WB/Serum \\
\hline Tsuji et al. (16) & 2000 & Japan & 0 & 5 & $1 / 4$ & $58.6(17.6)$ & 1 & 172 & $110 / 63$ & & p24, p40RNA & RT-PCR/PBMCS \\
\hline Tsuji et al. (16) & 2000 & Japan & 0 & 19 & $6 / 13$ & $50.7(14.2)$ & 0 & 210 & $129 / 81$ & & $\begin{array}{c}\text { Anti p24, p40 or } \\
\text { gp18 Ab }\end{array}$ & WB/Plasma \\
\hline Matsunaga et al. (35) & 2008 & Japan & 25 & 104 & $38 / 91$ & $49.5(16.4)$ & 67 & 209 & & & Anti p40, p24Ab & RLA/Serum \\
\hline Billich et al. (29) & 2002 & German! & 8 & 11 & $4 / 15$ & 53 & 14 & 50 & & & & IFA/Serum \\
\hline Billich (29) & 2002 & Germany & 4 & 15 & $4 / 15$ & 53 & 7 & 57 & & & $\mathrm{~N}, \mathrm{P}$ proteins & $\begin{array}{c}\text { Peptide } \\
\text { array/Serum }\end{array}$ \\
\hline Fukuda et al. (30) & 2001 & Japan & 1 & 44 & $23 / 22$ & 47 & 0 & 45 & $22 / 23$ & 48 & $\begin{array}{l}\text { Anti p24, p40 } \\
\text { Ab }\end{array}$ & WB/ Plasma \\
\hline Fukuda et al. (30) & 2001 & Japan & 1 & 44 & $23 / 22$ & 47 & 0 & 45 & $22 / 23$ & 48 & P24 RNA & $\begin{array}{l}\text { NestedRT- } \\
\text { PCR/PBMCS }\end{array}$ \\
\hline Fukuda et al. (30) & 2001 & Japan & 1 & 44 & $23 / 22$ & 47 & 1 & 44 & $22 / 23$ & 48 & $\begin{array}{l}\text { Anti p24, p40 } \\
\text { Ab }\end{array}$ & ECLIA/Plasma \\
\hline Fukuda et al. (30) & 2001 & Japan & 4 & 41 & $23 / 22$ & 47 & 1 & 44 & $22 / 23$ & 48 & $\begin{array}{l}\text { p24, p40 } \\
\text { proteins }\end{array}$ & $\begin{array}{l}\text { Proliferation } \\
\text { assay/Plasma }\end{array}$ \\
\hline Na et al. (15) & 2009 & Korea & 0 & $\begin{array}{c}138 \\
\text { (98MDD,40BD) }\end{array}$ & & & 0 & 60 & & & Anti BDV Ab & IFA/Serum \\
\hline Na et al. (15) & 2009 & Korea & 0 & $\begin{array}{c}138 \\
(98 \mathrm{MDD}, 40 \mathrm{BD})\end{array}$ & & & 0 & 60 & & & p24, p40RNA & RT-PCR/PBMCS \\
\hline Sauder et al. (37) & 1996 & Germany & 6 & 46 & & & 3 & 200 & & & $\begin{array}{c}\text { antip24, } \\
\text { p40,p16Ab }\end{array}$ & WB/Serum \\
\hline Planz et al. (38) & 1999 & German! & 2 & 0 & & & 0 & 3 & & & P4ORNA & $\begin{array}{c}\text { RT- } \\
\text { PCR/Granulocytes }\end{array}$ \\
\hline Salvator et al. (39) & 1997 & USA & $2(\mathrm{BD})$ & $9(6 \mathrm{MDD}, 3 \mathrm{BD})$ & & & 0 & 10 & & & P24RNA & RT-PCR/Brain \\
\hline Iwata et al. (40) & 1998 & Kubo & 2 & 47 & $25 / 24$ & $47.5(12.6)$ & 2 & 82 & $49 / 35$ & $45.2(10.2)$ & P24RNA & RT-PCR/PBMCS \\
\hline Kubo $(43)$ & 1997 & Japan & 1 & 122 & $42 / 81$ & $\begin{array}{c}52.95 \\
(13.24)\end{array}$ & 0 & 70 & $37 / 33$ & $\begin{array}{l}45.43 \\
(11.04)\end{array}$ & Anti BDV Ab & IFA/plasma \\
\hline Matsunaga et al. (44) & 2005 & Japan & 6 & 74 & $22 / 58$ & $46(16.9)$ & 1 & 40 & $19 / 22$ & $45.5(13.9)$ & $\begin{array}{l}\text { Anti BDV-P and } \\
\text { NAb }\end{array}$ & RLA/Serum \\
\hline Tehrani (17) & 2014 & Iran & $5(\mathrm{BD})$ & $\begin{array}{l}76(12 \mathrm{MDD} \\
59 \mathrm{BD})\end{array}$ & $37 / 44$ & & 8 & 192 & $111 / 89$ & & Anti BDV Ab & EIA/Plasma \\
\hline Tehrani et al. (17) & 2014 & Iran & $\begin{array}{l}37 \text { (6MDD, } \\
29 \mathrm{BD})\end{array}$ & $\begin{array}{l}44 \text { (6MDD, } \\
36 \mathrm{BD})\end{array}$ & $37 / 44$ & & 59 & 141 & $111 / 89$ & & CIC & EIA/Plasma \\
\hline Tehrani et al. (17) & 2014 & Iran & 0 & 81 & $37 / 44$ & & 2 & 198 & $111 / 89$ & & $\mathrm{~N}, \mathrm{P}$ proteins & EIA/Plasma \\
\hline Horing et al. (18) & 2012 & USA & $2(\mathrm{BD})$ & $\begin{array}{c}144 \\
\text { (80MDD,64BD) }\end{array}$ & & & 1 & 145 & & & Anti BDV Ab & IFA/Serum \\
\hline Horing et al. (18) & 2012 & USA & 0 & 146 & & & 0 & 146 & & & $\begin{array}{l}\text { Anti BDV-P and } \\
\text { NAb }\end{array}$ & ELISA/Serum \\
\hline Horing et al. (18) & 2012 & USA & 0 & 146 & & & 0 & 146 & & & P23,P40 RNA & RT-PCR/WBC \\
\hline Shankar et al. (45) & 1992 & USA & 0 & 5 & & & 0 & 20 & & & BDV RNA & RT-PCR/Brain \\
\hline Zhao et al. (46) & 2007 & China & 3 & 57 & & & 0 & 120 & & & P24 RNA & RT-PCR/PBMCS \\
\hline Wang et al. (47) & 2006 & China & 6 & 47 & & & 0 & 32 & & & P24 RNA & RT-PCR/PBMCS \\
\hline Flower et al. (48) & 2008 & Australie & 5 & 99 & & & 5 & 214 & & & $\begin{array}{l}\text { Anti p24 and } \\
\text { p40Ab }\end{array}$ & ELISA/Serum \\
\hline Flower et al. (48) & 2008 & Australia & 1 & 103 & & & 2 & 217 & & & $\begin{array}{l}\text { P24 and p40 } \\
\text { pAg }\end{array}$ & ELISA/Serum \\
\hline Bode et al. (49) & 1992 & German! & $\begin{array}{c}12 \\
(5 \mathrm{MDD}, 7 \mathrm{BD})\end{array}$ & $\begin{array}{c}538 \\
(358 \mathrm{MDD}, 180 \mathrm{BD})\end{array}$ & & $45(13)$ & 11 & 472 & & & Anti38/80KDAb & IFA/Serum \\
\hline Bode et al. (13) & 1995 & Germany & $2(\mathrm{MDD})$ & 1 (MDD) & ‘ & & 0 & 10 & & & P24, P40RNA & $\begin{array}{c}\text { Nested } \\
\text { RT-PCR/PBMCS }\end{array}$ \\
\hline Liu et al. (50) & 2015 & China & 97 (MDD) & 437 (MDD) & $187 / 347$ & $\begin{array}{l}35.99 \\
(12.33)\end{array}$ & 176 & 819 & $342 / 653$ & & CIC & EIA/Plasma \\
\hline Liu et al. (50) & 2015 & China & $5(\mathrm{MDD})$ & 95 (MDD) & & & 9 & 171 & & & Anti BDV ab & EIA/Plasma \\
\hline Liu et al. (50) & 2015 & China & 27 (MDD) & 507 (MDD) & $187 / 347$ & $\begin{array}{l}35.99 \\
(12.33)\end{array}$ & 58 & 937 & $342 / 653$ & & BDVp24RNA & RT-PCR/PBMCS \\
\hline
\end{tabular}




\section{References}

1. Whiteford HA, Ferrari AJ, Degenhardt L, Feigin V, Vos T. The global burden of mental, neurological and substance use disorders: an analysis from the Global Burden of Disease Study 2010. PLoS One. 2015;10(2). e0116820. doi:10.1371/journal.pone.0116820. [PubMed: 25658103].

2. Polanczyk GV, Salum GA, Sugaya LS, Caye A, Rohde LA. Annual research review: A meta-analysis of the worldwide prevalence of mental disorders in children and adolescents. J Child Psychol Psychiatry. 2015;56(3):345-65. doi: 10.1111/jcpp.12381. [PubMed: 25649325].

3. Karel MJ, Gatz M, Smyer MA. Aging and mental health in the decade ahead: what psychologists need to know. Am Psychol. 2012;67(3):18498. doi: 10.1037/a0025393. [PubMed: 21942364].

4. Reynolds K, Pietrzak RH, El-Gabalawy R, Mackenzie CS, Sareen J. Prevalence of psychiatric disorders in U.S. older adults: findings from a nationally representative survey. World Psychiatry. 2015;14(1):74-81. doi: 10.1002/wps.20193. [PubMed: 25655161].

5. Hughes E, Bassi S, Gilbody S, Bland M, Martin F. Prevalence of HIV, hepatitis $B$, and hepatitis $C$ in people with severe mental illness: a systematic review and meta-analysis. Lancet Psychiatry. 2016;3(1):40-8. doi: 10.1016/S2215-0366(15)00357-0. [PubMed: 26620388].

6. Lagios K, Deane FP. Severe mental illness is a new risk marker for blood-borne viruses and sexually transmitted infections. Aust N Z J Public Health. 2007;31(6):562-6. doi: 10.1111/j.1753-6405.2007.00144.x. [PubMed: 18081578].

7. Campos LN, Guimaraes MD, Carmo RA, Melo AP, Oliveira HN, Elkington $\mathrm{K}$, et al. HIV, syphilis, and hepatitis B and C prevalence among patients with mental illness: a review of the literature. Cad Saude Publica. 2008;24 Suppl 4:s607-20. [PubMed: 18797734].

8. Lipkin WI, Briese T, Hornig M. Borna disease virus - fact and fantasy. Virus Res. 2011;162(1-2):162-72. doi: 10.1016/j.virusres.2011.09.036. [PubMed: 21968299].

9. Tomonaga K, Kobayashi T, Ikuta K. Molecular and cellular biology of Borna disease virus infection. Microbes Infect. 2002;4(4):491-500. [PubMed: 11932200].

10. Lipkin WI, Briese T . Fields Virology. Bornaviridae. In: Knipe D, Howley P, Griffin D, Lamb R, Martin M, Roizman B, editors, et al. Philadelphia PA: Lippincott Williams and Wilkins; 2007. p. 1829-51.

11. Gonzalez-Dunia D, Volmer R, Mayer D, Schwemmle M. Borna disease virus interference with neuronal plasticity. Virus Res. 2005;111(2):22434. doi:10.1016/j.virusres.2005.04.011. [PubMed:15885838].

12. Bechter K, Herzog S, Behr W, Schuttler R. Investigations of cerebrospinal fluid in Borna disease virus seropositive psychiatric patients. Eur Psychiatry. 1995;10(5):250-8. doi: 10.1016/09249338(96)80302-6. [PubMed: 19698348].

13. Bode L, Zimmermann W, Ferszt R, Steinbach F, Ludwig H. Borna disease virus genome transcribed and expressed in psychiatric patients. Nat Med.1995;1(3):232-6. [PubMed: 7585039].

14. Li Q, Wang Z, Zhu D, Xu M, Chen X, Peng D, et al. Detection and analysis of Borna disease virus in Chinese patients with neurological disorders. Eur J Neurol. 2009;16(3):399-403. doi: 10.1111/j.14681331.2008.02516.x. [PubMed: 19364367].

15. Na KS, Tae SH, Song JW, Kim YK. Failure to detect borna disease virus antibody and RNA from peripheral blood mononuclear cells of psychiatric patients. Psychiatry Investig. 2009;6(4):306-12. doi: 10.4306/pi.2009.6.4.306. [PubMed: 20140130].

16. Tsuji K, Toyomasu K, Imamura Y, Maeda H, Toyoda T. No association of borna disease virus with psychiatric disorders among patients in northern Kyushu, Japan. J Med Virol. 2000;61(3):336-40. [PubMed: 10861642].

17. Mazaheri-Tehrani E, Maghsoudi N, Shams J, Soori H, Atashi H, Motamedi F, et al. Borna disease virus (BDV) infection in psychiatric pa- tients and healthy controls in Iran. Virol J. 2014;11:161. doi: 10.1186/1743422X-11-161. [PubMed: 25186971].

18. Hornig M, Briese T, Licinio J, Khabbaz RF, Altshuler LL, Potkin SG et al. Absence of evidence for bornavirus infection in schizophrenia, bipolar disorder and major depressive disorder. Mol Psychiatry. 2012;17(5):486-93. doi: 10.1038/mp.2011.179. [PubMed: 22290118]

19. Sayehmiri K, Tavan H, Sayehmiri F, Mohammadi I, V. Carson K. Prevalence of epilepsy in iran: a meta-analysis and systematic review. Iran J Child Neurol. 2014;8(4):9-17. [PubMed: 25657765].

20. Moher D, Liberati A, Tetzlaff J, Altman DG, Prisma Group . Preferred reporting items for systematic reviews and meta-analyses: the PRISMA statement. PLoS Med. 2009;6(7). e1000097. doi: 10.1371/journal.pmed.1000097. [PubMed:19621072].

21. Sayehmiri K, Tavan H, Sayehmiri F, Mohammadi I. Prevalence of epilepsy in iran: a meta-analysis and systematic review. ZUMSJ. 2015;23(97):112-21.

22. Wells GA, Shea B, O'Connell D, Peterson J, Welch V, Losos M, et al. The Newcastle-Ottawa Scale (NOS) for assessing the quality of nonrandomised studies in meta-analyses. 2011, [cited 2012 Nov 25]. Available from: http: //www.ohri.ca/programs/clinical_epidemiology/oxford.asp.

23. Ades AE, Lu G, Higgins JP. The interpretation of random-effects metaanalysis in decision models. Med Decis Making. 2005;25(6):646-54. doi: 10.1177/0272989X05282643. [PubMed: 16282215].

24. Chalmers RM, Thomas DR, Salmon RL. Borna disease virus and the evidence for human pathogenicity: a systematic review. QJM. 2005;98(4):255-74. doi: 10.1093/qjmed/hci039. [PubMed:15760926].

25. Azami M, Azizi Jalilian F, Khorshidi A, Mohammadi Y, Tardeh Z. The Association between Borna Disease Virus and Schizophrenia: A systematic review and meta-analysis. Asian J Psychiatr. 2017;34:67-73. doi: 10.1016/j.ajp.2017.11.026.

26. Azami M, Adhami Mojarad MR, Mansouri A, Tardeh Z. The Association Between Borna Disease Virus and Chronic Fatigue Syndrome: A Systematic Review and Meta-Analysis. Iran J Psychiatr Behav Sci. 2017;11(3) doi: 10.5812/ijpbs.9074.

27. Wang $X$, Zhang L, Lei Y, Liu X, Zhou X, Liu Y, et al. Meta-analysis of infectious agents and depression. Sci Rep. 2014;4:4530. doi: 10.1038/srep04530. [PubMed: 24681753].

28. Durrwald R, Kolodziejek J, Herzog S, Nowotny N. Meta-analysis of putative human bornavirus sequences fails to provide evidence implicating Borna disease virus in mental illness. Rev Med Virol. 2007;17(3):181-203. doi:10.1002/rmv.530. [PubMed: 17342788].

29. Billich C, Sauder C, Frank R, Herzog S, Bechter K, Takahashi K, et al High-avidity human serum antibodies recognizing linear epitopes of Borna disease virus proteins. Biol Psychiatry. 2002;51(12):979-87. [PubMed: 12062882].

30. Fukuda K, Takahashi K, Iwata Y, Mori N, Gonda K, Ogawa T, et al. Immunological and PCR analyses for Borna disease virus in psychiatric patients and blood donors in Japan.JClin Microbiol. 2001;39(2):419-29. doi: 10.1128/JCM.39.2.419-429.2001. [PubMed: 11158085].

31. Yamaguchi K, Sawada T, Naraki T, Igata-Yi R, Shiraki H, Horii Y, et al. Detection of borna disease virus-reactive antibodies from patients with psychiatric disorders and from horses by electrochemiluminescence immunoassay. Clin Diagn Lab Immunol. 1999;6(5):696-700. [PubMed: 10473520].

32. Amsterdam JD, Winokur A, Dyson W, Herzog S, Gonzalez F, Rott R, et al. Borna disease virus. A possible etiologic factor in human affective disorders? Arch Gen Psychiatry. 1985;42(11):1093-6. [PubMed: 3931604]

33. Fu ZF, Amsterdam JD, Kao M, Shankar V, Koprowski H, Dietzschold B. Detection of Borna disease virus-reactive antibodies from patients with affective disorders by western immunoblot technique. J Affect Disord.1993;27(1):61-8. [PubMed: 8432962].

34. Terayama H, Nishino Y, Kishi M, Ikuta K, Itoh M, Iwahashi K. Detection of anti-Borna Disease Virus (BDV) antibodies from patients 
with schizophrenia and mood disorders in Japan. Psychiatry Res. 2003;120(2):201-6. [PubMed: 14527651].

35. Matsunaga H, Tanaka S, Fukumori A, Tomonaga K, Ikuta K, Amino $\mathrm{N}$, et al. Isotype analysis of human anti-Borna disease virus antibodies in Japanese psychiatric and general population. J Clin Virol. 2008;43(3):317-22. doi: 10.1016/j.jcv.2008.07.011. [PubMed: 18786855].

36. de la Torre JC, Bode L, Durrwald R, Cubitt B, Ludwig H. Sequence characterization of human Borna disease virus. Virus Res.1996;44(1):33-44. [PubMed: 8873411].

37. Sauder C, Muller A, Cubitt B, Mayer J, Steinmetz J, Trabert W, et al. Detection of Borna disease virus (BDV) antibodies and BDV RNA in psychiatric patients: evidence for high sequence conservation of human blood-derived BDV RNA. J Virol. 1996;70(11):7713-24. [PubMed: 8892892].

38. Planz O, Rentzsch C, Batra A, Winkler T, Buttner M, Rziha HJ, et al. Pathogenesis of borna disease virus: granulocyte fractions of psychiatric patients harbor infectious virus in the absence of antiviral antibodies. J Virol. 1999;73(8):6251-6. [PubMed: 10400715].

39. Salvatore M, Morzunov S, Schwemmle M, Lipkin WI. Borna disease virus in brains of North American and European people with schizophrenia and bipolar disorder. Bornavirus Study Group. Lancet. 1997;349(9068):1813-4. [PubMed: 9269221].

40. Iwata Y, Takahashi K, Peng X, Fukuda K, Ohno K, Ogawa T, et al. Detection and sequence analysis of borna disease virus p24 RNA from peripheral blood mononuclear cells of patients with mood disorders or schizophrenia and of blood donors. J Virol. 1998;72(12):10044-9. [PubMed: 9811743].

41. Czygan M, Hallensleben W, Hofer M, Pollak S, Sauder C, Bilzer T, et al Borna disease virus in human brains with a rare form of hippocampal degeneration but not in brains of patients with common neuropsychiatric disorders. J Infect Dis. 1999;180(5):1695-9. doi: 10.1086/315068. [PubMed: 10515835].

42. Nunes SO, Itano EN, Amarante MK, Reiche EM, Miranda HC, de Oliveira
$\mathrm{CE}$, et al. RNA from Borna disease virus in patients with schizophrenia, schizoaffective patients, and in their biological relatives.J Clin Lab Anal. 2008;22(4):314-20. doi: 10.1002/jcla.20261. [PubMed: 18623121].

43. Kubo K, Fujiyoshi T, Yokoyama MM, Kamei K, Richt JA, Kitze B, et al. Lack of association of Borna disease virus and human T-cell leukemia virus type 1 infections with psychiatric disorders among Japanese patients. Clin Diagn Lab Immunol. 1997;4(2):189-94. [PubMed: 9067654].

44. Matsunaga H, Tanaka S, Sasao F, Nishino Y, Takeda M, Tomonaga K, et al. Detection by radioligand assay of antibodies against Borna disease virus in patients with various psychiatric disorders. Clin Diagn Lab Immunol. 2005;12(5):671-6. doi: 10.1128/CDLI.12.5.671-676.2005. [PubMed: 15879032].

45. Shankar V, Dietzschold B, Fu ZF, Amsterdam J. A search for borna virus-specific genome in human nerve tissue by reverse transcriptase polymerase chain reaction (RT-PCR). Biol Psychiatr. 1992;31(5):103. doi: 10.1016/0006-3223(92)90449-a.

46. Zhao LB, Xie P, Mu J, Li YJ, Zou DZ, Liu QJ, et al. Molecular biological research on borna disease virus infection in depressive patients of chongqing. Airiti Lib. 2007;33(1):18-22.

47. Wang ZH, Xie P, Han YX, Zhan J. [Study on molecular epidemiology of Borna disease virus in Ningxia and vicinal regions]. Zhonghua Liu Xing Bing Xue Za Zhi. 2006;27(6):479-82. [PubMed: 17152506].

48. Flower RL, Kamhieh S, McLean L, Bode L, Ludwig H, Ward CM. Human Borna disease virus infection in Australia: serological markers of infection in multi-transfused patients. APMIS Suppl. 2008;(124):8993. [PubMed: 18771108].

49. Bode L, Riegel S, Lange W, Ludwig H. Human infections with Borna disease virus: seroprevalence in patients with chronic diseases and healthy individuals. J Med Virol. 1992;36(4):309-15. [PubMed: 1578223].

50. Liu X, Bode L, Zhang L, Wang X, Liu S, Zhang L, et al. Health care professionals at risk of infection with Borna disease virus - evidence from a large hospital in China (Chongqing). Virol J. 2015;12:39. doi: 10.1186/s12985-015-0239-y. [PubMed: 25888756]. 